\title{
Increasing Number of Unusual Brain Abnormalities Seen in Rural West Virginia
}

Taylor R. Maddox, MS' ${ }^{1}$, Jessica Haas, MSN, RN², Lacey Andrews, MS³, Hannah Redman, MS ${ }^{1}$, Balaji Govindaswami, MD, MPH' ${ }^{1}$, Todd H. Davies, PhD ${ }^{1}$

The incidence rate of schizencephaly is 1.5 in 100,000 live births and the rate of article. holoprosencephaly is 1 in 16,000 live births. Both malformations are rare, but our institution has seen a dramatic increase in both malformations in recent years with no known cause. Schizencephaly is the most severe cortical malformation and holoprosencephaly is the most common defect in the prosencephalon during development. However, it is still not very common to see a fetus with this defect live to delivery. Our institution, a regional hospital in central Appalachia, has seen four cases of schizencephaly and three cases of holoprosencephaly within two years. No two neonates seem to share a common factor. All had different co-morbidities and presentations, all mothers were of different ages and showed few risk factors if any for these deformities. This paper is a report of the cases found of these rare birth defects seen at our institution in recent years.

\section{KEYWORDS}

Neonate, Holoprosencephaly, Schizencephaly

\section{INTRODUCTION}

Our institution, a regional hospital in central Appalachia, has seen an unusual increase in brain abnormalities over the past ten years with no obvious cause, with a cluster of severe congenital brain malformations in the last thirty months. These malformations include schizencephaly and holoprosencephaly. Schizencephaly is the most severe form of a cortical malformation. ${ }^{1}$ Schizencephaly is estimated to affect 1.5 out of 100,000 live births. The clefting of the cerebral mantle most commonly occurs in the frontal lobes but can occur in the parietal lobe as well.2 Schizencephaly symptoms include developmental delays, speech and language difficulties, brainspinal cord communication problems, microcephaly, hydrocephalus, seizures, complete or partial paralysis, and abnormal muscle tone. The severity of the persons' symptoms depends on cleft severity and the presence of other brain abnormalities. ${ }^{3}$ There is no known cause of schizencephaly, but it has been linked to genes EMX2, SIX3, SHH, and COL4A1. There are also non-genetic links such as maternal age under twenty-four years old, infections during gestation specifically cytomegalovirus infection (CMV), folate deficiency, and exposure to medication during development that can interrupt blood flow before birth. ${ }^{4,5}$ There is no cure for this malformation. There is still little known about schizencephaly and more research needs to be done in this area.

Holoprosencephaly (HPE) is the most common malformation of the prosencephalon, occurring in 1 in 250 embryos and 1 in 16,000 live births. ${ }^{6}$ This defect will occur within the first four weeks of embryogenesis; it is said to be as specific as between the 18th and 28th day after conception. HPE affects $3-4 \%$ of all live births. ${ }^{7,8} \mathrm{HPE}$ is a nonseparation of the deep grey nuclei, and this is used to diagnose a spectrum of disorders with the same etiology. Of this spectrum of disorders, the diagnoses are graded on the degree of non-separation of the nuclei. The severity of the craniofacial malformations is dependent on the degree of nonseparation of the grey nuclei. With HPE cases it has been said that "the 
face follows the brain" meaning the severity of the malformation will correlate to the separation or lack thereof within the brain. ${ }^{6,9,10}$ The risk factors for a fetus developing HPE can include a maternal obstetrical history of a previous spontaneous abortion, first trimester bleeding during the pregnancy in question or previous pregnancies, and/or chromosomal abnormalities. Several of the recognized maternal risk factors are diabetes mellitus gestational or chronic, alcoholism, smoking, prenatal exposure to retinoic acid, cholesterol biosynthetic inhibitors, infections, and hypothyroidism. ${ }^{10}$ Other possible risk factors include the use of contraceptives, before or early during the pregnancy, the use of salicylates, hypocholesterolemia, low-calorie diets, and cholesterol synthesis via the Sonic hedgehog $(\mathrm{SHH})$ pathway. ${ }^{11}$

The population our institution serves has had numerous high-risk factors for these brain malformations for years with the highest rate nationally for diabetes ${ }^{12}$, smoking during pregnancy ${ }^{12,13}$, and heart disease. ${ }^{13}$ Considering all of the risk factors and the prevalence of these decreasing within this population over the past few years, it is unclear what could have caused a seemingly random spike in the rates of these very specific birth defects or why these are the first our institution has seen. When based on the rates of teratogens from previous years present in this population, we should have been seeing them all along. This study aims to discuss this cluster of rare brain anomalies that were seen in a close time frame and proximity to our institution.

\section{CASE PRESENTATION}

The finding of a single case of HPE is rare; the rate of HPE in live births is 1 in 16,000 newborns. Within two years our institution diagnosed four cases of schizencephaly. Also, during these two years, in less than seven months, our institution saw and diagnosed three cases of HPE, two males and one set of female twins; only one of the twins was formally diagnosed with HPE. There are no shared risk factors or genetic abnormalities among the presented cases. These neonates have no obvious cause of this malformation, and they all have very little if anything in common. The information about each of these neonates at birth and during pregnancy can be found in Table 1 under each case number for easy comparison.

\section{METHODS}

A retrospective analysis was completed to further examine the incidence of these two rare central nervous system malformations seen from 2017 until 2019. The schizencephaly cases are diagnosed by the degree of clefting seen in the cerebral mantle of the various lobes of the brain. Holoprosencephaly was confirmed by a lack of separation of the two hemispheres of the brain. All seven neonates' diagnoses were confirmed radiographically.

\section{RESULTS}

In the ten years from January first to the end of December 2019, seven neonates were born weighing 800 grams or greater and were diagnosed by the treating physicians as small for gestational age. ${ }^{14}$ Of these seven neonates, three were diagnosed with holoprosencephaly and the remaining four were diagnosed with schizencephaly. The details of these neonates can be seen in Table 1 .

\section{DISCUSSION}

The population in West Virginia has significant co-morbidities and lifestyle choices that all align with the literature for potential risk factors of brain malformation. Despite the high number of risk factors, no congenital brain malformations had been identified at our institution since the installation of our electronic medical record in 2008 , with no memory of additional cases from long-time staff. We have described the geographic cluster of rare and debilitating encephalopathies. With no previous cases recorded or in memory of the staff, and as rare as these malformations are embryologically, seven cases in just over two years is statistically improbable.

The children with schizencephaly (chronologically 


\begin{tabular}{|c|c|c|c|c|c|c|c|}
\hline Neonate & 1 & 2 & 3 & 4 & 5 & 6 & 7 \\
\hline Diagnosis & Schizencephaly & Holoprosencephaly & Holoprosencephaly & Schizencephaly & Holoprosencephaly & Schizencephaly & Schizencephaly \\
\hline Gender & male & male & male & male & female & female & female \\
\hline Delivery & repeat cesarean & cesarean & vaginal & cesarean & cesarean & vaginal & cesarean \\
\hline $\begin{array}{l}\text { Gestation age in } \\
\text { weeks }\end{array}$ & 30 & 27.5 & 36 & 34 & 31 & 36 & 32 \\
\hline $\begin{array}{l}\text { Birth weight in } \\
\text { grams and } \\
\text { gestational size }\end{array}$ & $\begin{array}{ll}-\quad & 1270 \\
-\quad & \text { SGA } \\
\end{array}$ & $\begin{array}{l}1080 \\
-\quad \text { SGA } \\
\end{array}$ & $\begin{array}{ll}- & 2645 \\
- & \text { SGA } \\
\end{array}$ & $\begin{array}{l}1360 \\
-\quad \text { SGA } \\
\end{array}$ & $\begin{array}{ll}- & 800 \\
\text { - } & \text { SGA } \\
\end{array}$ & $\begin{array}{ll}-\quad 2494 \\
-\quad & \text { SGA } \\
\end{array}$ & $\begin{array}{ll}- & 940 \\
\text { SGA }\end{array}$ \\
\hline $\begin{array}{l}\text { Birth head } \\
\text { circumference }\end{array}$ & 26 & 24.5 & 31 & 28 & 26 & 30 & 23 \\
\hline $\begin{array}{l}\text { APGAR scores } \\
\underline{1,5 \text { minute }}\end{array}$ & 6,8 & 5,8 & 8,8 & 5,8 & 5,8 & 9,9 & 6,8 \\
\hline $\begin{array}{l}\text { Complications } \\
\underline{\text { at birth }}\end{array}$ & $\begin{array}{l}\text { non-reassuring } \\
\text { fetal heart rate }\end{array}$ & None reported & None reported & None reported & $\begin{array}{l}\text { multiple gestation, } \\
\text { polyhydramnios }\end{array}$ & None reported & $\begin{array}{l}\text { non-reassuring } \\
\text { fetal heart rate }\end{array}$ \\
\hline $\begin{array}{l}\text { Maternal Age in } \\
\text { years }\end{array}$ & 28 & 17 & 18 & 22 & 37 & 18 & 27 \\
\hline Gravida Para & 2,1 & 1,0 & 1,0 & 2,1 & 3,2 & 2,1 & 2,1 \\
\hline $\begin{array}{l}\text { Maternal Blood } \\
\text { type }\end{array}$ & $\mathrm{A}^{+}$ & $\mathrm{O}+$ & $\mathrm{AB}+$ & $\mathrm{A}+$ & $\mathrm{O}+$ & $\mathrm{O}+$ & $\mathrm{B}+$ \\
\hline Maternal BMI & Unknown & Unknown & 22.7 & 29.8 & 26.4 & 24.7 & 24.6 \\
\hline $\begin{array}{l}\text { Maternal } \\
\text { medications } \\
\text { during } \\
\text { pregnancy }\end{array}$ & $\begin{array}{ll}\text { - } & \text { Prenatal } \\
& \text { vitamins } \\
\text { - } & \text { Betamethaso } \\
& \text { ne } \\
\text { - } & \text { Novolog } \\
\text { - } & \text { Reglan } \\
\text { - } & \text { Levemir } \\
\text { - } & \text { Meclizine } \\
\text { - } & \text { Verapamil } \\
\text { - } & \text { Vistaril } \\
\text { - } & \text { Opiates } \\
\text { - } & \text { Oxycodone } \\
\text { - } & \text { Barbiturates } \\
\end{array}$ & $\begin{array}{ll}\text { - } & \text { Prenatal vitamin } \\
\text { - } & \text { Albuterol } \\
\text { - Nifedipine }\end{array}$ & $\begin{array}{ll}\text { - } & \text { Prenatal } \\
\text { vitamins } \\
\text { - } \quad \text { ranitidine } \\
\text { - } & \text { hydroxyzine } \\
\text { - } & \text { metronidazole }\end{array}$ & $\begin{array}{l}\text { - Prenatal } \\
\text { vitamins } \\
\text { ranitidine }\end{array}$ & $\begin{array}{ll}\text { - } & \text { Prenatal } \\
\text { vitamins } \\
\text { - } & \text { ranitidine } \\
\text { - } & \text { hydroxyzine }\end{array}$ & $\begin{array}{ll}\text { - } & \text { None } \\
\text { reported }\end{array}$ & $\begin{array}{l}\text { - Prenatal } \\
\text { vitamins }\end{array}$ \\
\hline $\begin{array}{l}\text { Maternal } \\
\text { complications } \\
\text { during } \\
\text { pregnancy }\end{array}$ & $\begin{array}{l}\text { Severe pre- } \\
\text { eclampsia, } \\
\text { diabetes mellitus } \\
\text { type I, tobacco } \\
\text { use, hyperemesis } \\
\text { gravidarum, and } \\
\text { Substance Use } \\
\text { Disorder }\end{array}$ & $\begin{array}{l}\text { Asthma, } \\
\text { hypertension, and } \\
\text { tobacco use }\end{array}$ & $\begin{array}{l}\text { Intrauterine growth } \\
\text { restriction }\end{array}$ & $\begin{array}{l}\text { Hypertension, } \\
\text { gastroesophageal } \\
\text { reflux disease, } \\
\text { allergies previous } \\
\text { spontaneous } \\
\text { abortion, } \\
\text { polyhydramnios }\end{array}$ & $\begin{array}{l}\text { Multiple gestation, } \\
\text { polyhydramnios, } \\
\text { tobacco use, alcohol } \\
\text { use, advanced } \\
\text { maternal age, stage } \\
\text { III kidney disease }\end{array}$ & $\begin{array}{l}\text { Previous } \\
\text { spontaneous } \\
\text { abortion }\end{array}$ & $\begin{array}{l}\text { Congenital CMV, } \\
\text { intrauterine } \\
\text { growth } \\
\text { restriction, } \\
\text { cannabinoid use }\end{array}$ \\
\hline $\begin{array}{l}\text { Identified risk } \\
\text { factors }\end{array}$ & $\begin{array}{ll}\text { - } & \text { Multiple } \\
\text { illicit } \\
\text { substance } \\
\text { use } \\
\text { - } & \text { tobacco use } \\
\end{array}$ & - Tobacco use & - None identified & $\begin{array}{l}\text { Maternal age } \\
\text { under } 24\end{array}$ & $\begin{array}{ll}\text { - } & \text { Alcohol use } \\
\text { - } & \text { tobacco use } \\
\text { poor } \\
\text { obstetrical } \\
\text { history } \\
\end{array}$ & $\begin{array}{l}\text { Maternal } \\
\text { age under } \\
24\end{array}$ & $\begin{array}{l}\text { - CMV } \\
\text { infection } \\
\text { cannabinoid } \\
\text { use }\end{array}$ \\
\hline $\begin{array}{l}\frac{\text { Neonatal }}{\text { genetic testing }} \\
\text { - } \underline{\text { CGH }} \\
\text { FISH }\end{array}$ & $\begin{array}{ll}- & \text { Result } \\
\text { negative } \\
\text { normal } \\
\text { karyotype } \\
\text { - } & \text { Result } \\
& \text { negative } \\
\end{array}$ & 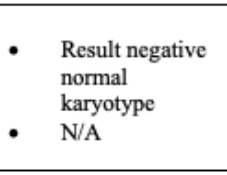 & $\begin{array}{ll}\text { - } & \text { Result negative } \\
\text { normal } \\
\text { karyotype } \\
\text { - } & \text { N/A }\end{array}$ & $\begin{array}{ll}\text { - } & \text { mosaic } \\
\text { terminal } \\
\text { duplication of } \\
\text { 10Q23.33 } \\
\text { - } \\
\text { N/A }\end{array}$ & $\begin{array}{l}\text { - } \quad \mathrm{N} / \mathrm{A} \\
\mathrm{N} / \mathrm{A}\end{array}$ & $\begin{array}{l}\text { - } \\
\text { N/A } \\
\text { N/A }\end{array}$ & $\begin{array}{l}\text { - } \quad \text { N/A } \\
\text { N/A }\end{array}$ \\
\hline
\end{tabular}

TABLE 1: This table compares the details of each case including the gestational age, weight, head circumference, APGAR scores, exposure to maternal medicines and substances and other details of the gestations and maternal history. The results of any genetic testing are also listed in the table above. All cases were determined by the treating physician to be small for gestational age (SGA). 
- 1, 4, 6, and 7) do not appear to have any common risk factors. The first had no risk factors that have been described in the literature. However, the mother did use multiple illicit substances (including opioids, amphetamines, and marijuana) of unknown quantities throughout her pregnancy. We can only speculate if this was a contributing factor to the malformation in this neonate. The fourth neonate's mother was 22 years old which is considered a risk factor for schizencephaly and upon genetic testing, it was found that the neonate had a gene duplication that was not thought to contribute to the brain malformation; the mother had no other risk factors described in the literature. The sixth neonate's mother was 18 years old and she had a previous spontaneous abortion; no genetic testing was performed for this child and so a contributing genetic variant cannot be identified as the cause but no other risk factors were found in the mother's history. The last child seen with schizencephaly had a confirmed CMV infection during gestation as the only confirmed risk factor.

The children with holoprosencephaly (chronologically - 2, 3, and 5), like the schizencephaly, have little identified commonalities. The second child had no abnormalities on genetic testing. The mother did admit to smoking cigarettes during her pregnancy with no other risk factors. The third child no known genetic abnormalities, no previous spontaneous abortion (SAB), no first trimester bleeding, no reported diabetes mellitus, no reported alcohol consumption, or tobacco usage during the pregnancy. This neonate was the only child that has no identified risk factors for this malformation. Whereas the fifth neonate had the most risk factors of all seven, this mother had many issues with her previous pregnancies, and the pregnancy discussed in this paper was complicated with multiple fetuses and polyhydramnios. The mother also admitted to smoking cigarettes and using alcohol during her pregnancy. Lemonie reported in a paper from 1968 that on the more severe end of the fetal alcohol spectrum there were malformations of the brain some of which include semi-lobar holoprosencephaly and agenesis or absence of the corpus callosum. ${ }^{15}$

The first, third, and fourth neonates received genetic testing by microarray-based Comparative Genomic
Hybridization (CGH); the first and third neonates were negative and the fourth was considered to have a minor duplication of no consequence to this malformation. In all seven cases, the umbilical cords were normal and unremarkable, except for the sixth whose cord was dried, and abnormalities could not be detected.

There was one common factor across the neonates in this series: all seven children discussed here were small for gestational age, which is unusual in this population. Fetal insulin is the hormonal regulator for fetal growth during gestation, the amount of insulin is dependent on the amount of glucose the fetus attains from the mother's blood.16,17 The maternal BMI can be seen in Table 1. BMI has been correlated to insulin secretion and sensitivity.18,19 Fetal insulin secretion is the primary regulator for growth during development, if the mother had an increased glycemic index it would be more likely for their child to be appropriate or large for their gestational age. However, in the seven children, we have seen with these malformations only two of the mothers (the fourth and fifth) were overweight and both neonates were still small for their gestational age. The mothers of the third, sixth, and seventh all had BMIs in the normal range and the children were also small for gestational age. The first and second mothers' information on their BMls could not be found.

It is likely we will not find the definitive cause of these malformations. More research needs to be done into the causes of the malformations and the rural Appalachian population. It is not clear what may have caused this crop of encephalopathies in such a short time or if this is not an arbitrary occurrence and this is the new normal for our population. We need more research into the causes and the treatments of these malformations to best serve our community.

Within the last ten years, two other clusters of birth defects have been seen at our institution. The two clusters that have been seen were five cases of myelomeningocele within two years and six cases of imperforated anus over ten years; however, four of these cases were within two years. Due to the proximity geographically of these cases to one another, environmental teratogenic exposure has 


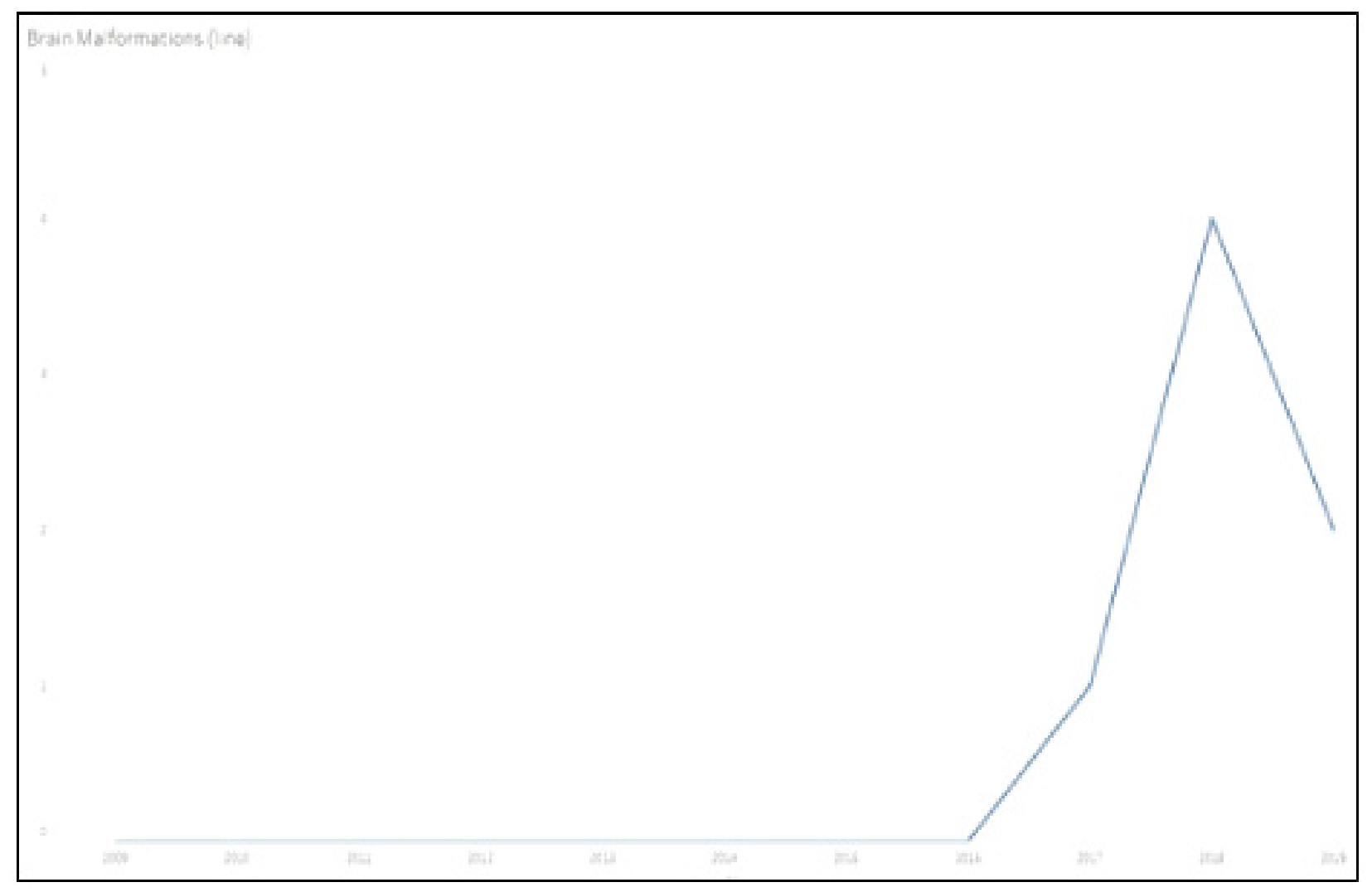

GRAPH 1: This graph is a timeline of brain malformations seen at our institution from 2009 to 2019.

been hypothesized and should be explored for a more complete investigation as to the potential causes of these malformations.

\section{CONCLUSION}

Our institution has witnessed a recent and unprecedented increase in infants diagnosed with schizencephaly and holoprosencephaly with no known cause. A timeline with these cases can be seen in Graph 1. The population we serve exhibits a great many risk factors and co-morbidities and has for years. However, we are only now seeing the presentation of this malformation and other birth abnormalities with no obvious cause. Without more information about the pregnancies and exposures, we can only speculate as to the causes. To find such a cause and/or more risk factors that can lead to the development of this encephalopathy, more research and investigation needs to be done.

\section{AUTHOR AFFILIATIONS}

1. Marshall University Joan C. Edwards School of Medicine, Huntington, West Virginia

2. Hoops Family Children's Hospital at Cabell Huntington Hospital, Huntington, West Virginia

3. Vanderbilt University Medical Center, Nashville, Tennessee

\section{REFERENCES}

1. Volpe J, Inder T, Darras B, de Vries L, du Plessis A, Neil J, Perlman J..Volpe's Neurology of the Newborn. 6th ed: Elsevier; 2017.

2. Stopa J, Kucharska-Miąsik I, Dziurzyńska-Białek $\mathrm{E}$, et al. Diagnostic imaging and problems of schizencephaly. Pol J Radiol 2014;79:444-9.

3. Schizencepephaly: Genetic and Rare Diseases Information Center. National Center for Advancing Translational Sciences. (Accessed 19 Feb 2020, at https://rarediseases.info.nih.gov/ 


\section{diseases/166/schizencephaly.)}

4. Howe DT, Rankin J, Draper ES. Schizencephaly prevalence, prenatal diagnosis and clues to etiology: a register-based study. Ultrasound in Obstetrics \& Gynecology 2012;39:75-82.

5. We are Rare: Schizencephaly. We Are R.A.R.E. (Accessed 19 Feb 2020, at http://wearerare.org/ schizencephaly/.)

6. Holoprosencephaly: Genetic and Rare Diseases Information Center. National Center for Advancing Translational Sciences. (Accessed 19 Feb 2020, at https://rarediseases.info.nih.gov/ diseases/6665/holoprosencephaly/cases/27877.)

7. Stashinko EE, Clegg NJ, Kammann HA, et al. A retrospective survey of perinatal risk factors of 104 living children with holoprosencephaly. Am J Med Genet A 2004;128A:114-9.

8. Levey EB, Stashinko E, Clegg NJ, Delgado MR. Management of children with holoprosencephaly. Am J Med Genet C Semin Med Genet 2010;154C:183-90.

9. Kauvar EF, Muenke M. Holoprosencephaly: recommendations for diagnosis and management. Curr Opin Pediatr 2010;22:687-95.

10. Dubourg C, Bendavid C, Pasquier L, Henry C, Odent S, David V. Holoprosencephaly. Orphanet J Rare Dis 2007;2:8.

11. Woollett LA. Review: Transport of maternal cholesterol to the fetal circulation. Placenta 2011;32 Suppl 2:S218-S21.

12. WV Department of Health and Human Resources HSC. West Virginia Behavioral Risk Factor Surveillance System Report, 20162018.

13. America's Health Rankings analysis of CDC WONDER Online Database, Natality public-use data. United Health Foundation. (Accessed 19 Feb 2020, at https://www. americashealthrankings.org/explore/healthof-women-and-children/measure/Smoking pregnancy/state/WV.)

14. Kiserud T, Piaggio G, Carroli G, et al. The World Health Organization Fetal Growth Charts: A Multinational Longitudinal Study of Ultrasound Biometric Measurements and Estimated Fetal Weight. PLoS Med 2017;14:e1002220.

15. Lemoine $P$, Harousseau $H$, Borteyru JP, Menuet JC. Children of alcoholic parents--observed anomalies: discussion of 127 cases. Ther Drug Monit 1968;25:132-6.

16. Fowden AL. The role of insulin in fetal growth.
Early Hum Dev 1992;29:177-81.

17. Fowden AL. Insulin deficiency: effects on fetal growth and development. J Paediatr Child Health 1993;29:6-11.

18. Anstey KJ, Christensen $\mathrm{H}$, Butterworth $\mathrm{P}$, et al. Cohort profile: the PATH through life project. Int J Epidemiol 2012;41:951-60.

19. Walsh El, Shaw J, Cherbuin N. Trajectories of BMI change impact glucose and insulin metabolism. Nutr Metab Cardiovasc Dis 2018;28:243-51. 